\title{
Journal of Food and Dairy Sciences
}

Journal homepage: www.jfds.mans.edu.eg

Available online at: www. jfds.journals.ekb.eg

\section{Production of Probiotic Low-Fat Yoghurt Supplemented with Guava Seeds Powder}

\author{
Abd El-Sattar, E. ${ }^{1 *}$; Mahetab F. Ramadan² and E. M. Abd El-Wahed ${ }^{2}$ \\ ${ }^{1}$ Department of Food and Dairy Technology, Faculty of Technology and Development, Zagazig University, 44519 Zagazig, Cross Mark \\ Egypt. \\ ${ }^{2}$ Department of Food Science, Faculty of Agriculture, Zagazig University, 44511 Zagazig, Egypt.
}

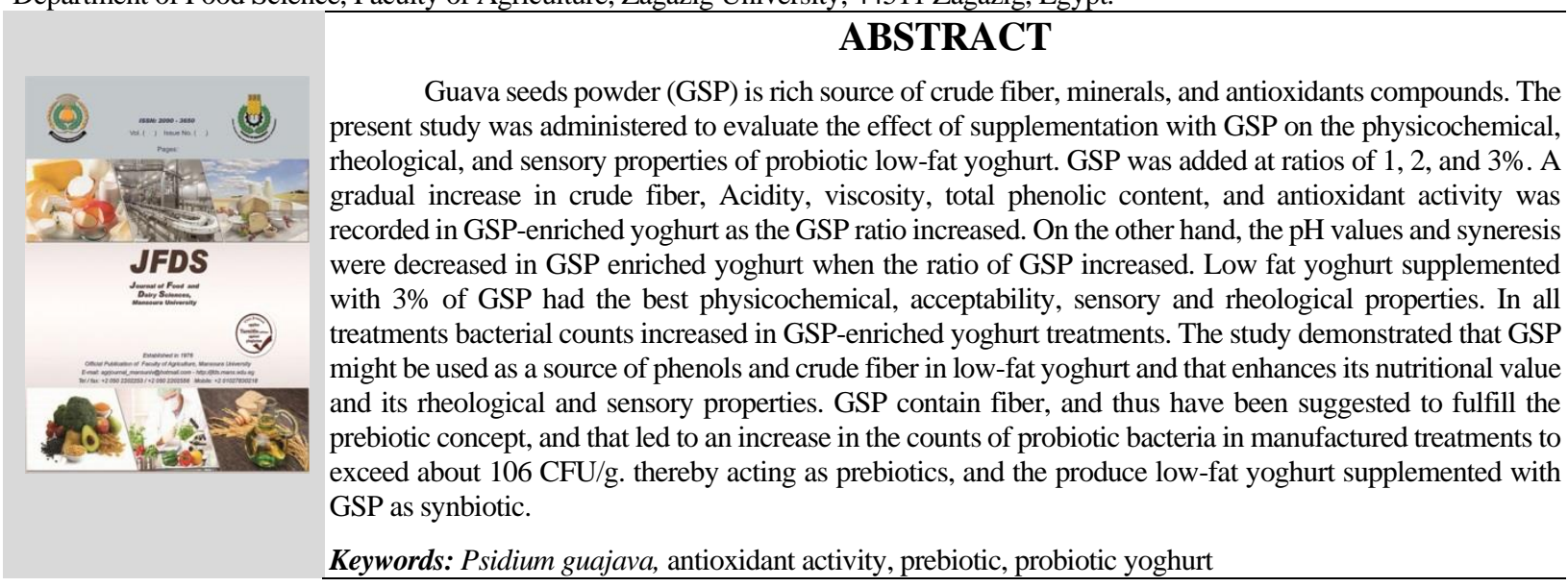

\section{INTRODUCTION}

The fruits and vegetables produced worldwide finish up as wastes. Most wastes are generated by industrial processing, the so-called by-products. These by-products still contain many bioactive compounds, such as macronutrients (proteins and carbohydrates) and phytochemicals. Recently, the recovery of those bioactive compounds from industrial by-products has received significant attention mainly due to their possible health benefits (Coman et al., 2020).

Guava (Psidium guajava L.) is a fruit cosmopolitan in tropical countries, especially in America, Asia, and Africa. The guava fruit is extremely appreciated by its high nutritional value. Guava seeds are the waste of fruit industry and aren't yet used for beneficial purpose. Guava seeds are particularly rich in minerals and functional compounds like vitamin C, crude fiber, carotenoids, and phenolic compounds (Usman et al., 2013.)

Yoghurt is one of the foremost consumed healthy and nutritious foodstuff worldwide. Yoghurt features a better digestibility of proteins than milk and positive effects on health by providing the physical body prebiotic and probiotic bacteria (Dabija et al., 2018). Low-fat dairy products including yoghurt have gained popularity due to consumer awareness about health concerns associated with decreasing the risks connected with obesity and coronary heart diseases (Sandoval et al., 2004). However, the partial or total removal of fat from yoghurt decreases the general quality perceived by the consumers (Folkenberg and Martens, 2003.)
Probiotics are live microorganisms that, when administered in adequate amounts, confer a health benefit on the host (Hill et al., 2014). The effective dose of probiotic bacteria is varied between $106 \mathrm{CFU} / \mathrm{g}$ to $109 \mathrm{CFU} / \mathrm{g}$ in a product for assured health benefits (Ganguly, et al., 2019). Wang et al. (2019) demonstrated that apple pomace features a potential as a DF source in stirred type yoghurt. Maqsood et al. (2019) reviewed the bioactive compounds and nutraceutical properties of various sorts of date fruit and seeds, also because of the potential of using them as functional food ingredients

This study was aimed to investigate the physicochemical, antioxidant activity and total phenolic content of GSP.As well as to evaluate the effect of the addition of GSP on physicochemical, rheological, microbiological and sensory properties of probiotic low-fat yoghurt.

\section{MATERIALS AND METHODS}

\section{Materials}

Fresh buffalo's milk (7.3\% fat) was obtained from the Dairy Technology Unit, Food Science Department, Faculty of Agriculture, Zagazig University, Egypt. It was standardized to $1 \%$ and $3 \%$ fat using milk separator and person square. Guava (Psidium guijava) ripe fruits were purchased from the local market (Zagazig, Egypt). Freeze dried DVS ABT-5 Probio-Tec $®$ cultures containing Streptococcus thermophilus, Lactobacillus acidophilus and Bifidobacterium BB-12 were obtained from Christian Hansen Laboratory Copenhagen, Denmark, by Misr Food Additives (MIFAD), Egypt . 
All chemicals used in different analyses were obtained from El-Gomhoria Company (Cairo, Egypt).

Methods

Preparation of guava seeds powder (GSP)

Guava fruits were crushed in fruit mill, then pulp was extracted from helicoidal juice extractor to obtain guava pomace. The seeds were cleaned, washed in running tap water and dried in tray drier oven at $60^{\circ} \mathrm{C}$ until constant weight. The dried seeds were ground to fine powder in an electric grinder to obtain guava seeds powder (GSP). GSP was stored in plastic bags and kept under refrigeration at $4{ }^{\circ} \mathrm{C}$ until used.

\section{Preparation of probiotic low-fat yoghurt}

The manufacture of probiotic low-fat yoghurt was experimented according to Tamime (2006) with some modifications. Two liters of buffalo's milk were standardized to $3 \%$ fat and used for making yoghurt served as a control (C1). Eight liters of buffalo's milk (1\% fat) was divided into 4 portions. The first portion was left without additive as a positive control $\left(\mathrm{C}_{2}\right)$, GSP was added to the other three portions at the rate of 1,2 and $3 \%\left(\mathrm{~T}_{1}, \mathrm{~T}_{2}\right.$ and, $\left.\mathrm{T}_{3}\right)$, respectively. The supplemented milk bases were heated to $80^{\circ} \mathrm{C}$ for $15 \mathrm{~min}$, then cooled to $42 \pm 1^{\circ} \mathrm{C}$, inoculated with $0.025 \%$ of ABT-5 culture, filled in plastic cups and incubated at $42^{\circ} \mathrm{C}$ until uniform coagulation was obtained. The yoghurt samples were kept at $7 \pm 2^{\circ} \mathrm{C}$ for 15 days .Yoghurt samples were analyzed when fresh and then after 5,10 and 15 days during storage. This experiment was triplicated

\section{Chemical analysis}

Total solids, fat, total protein, crude fiber contents, titratable acidity and $\mathrm{pH}$ of yoghurt samples were determined according to AOAC (2007). The changes in $\mathrm{pH}$ in the yoghurt samples during storage were measured using a laboratory $\mathrm{pH}$ meter with a glass electrode (HANNA, Instrument, Portugal).

\section{Determination of total phenolic content (TPC)}

The concentration of TPC was measured by a UV spectrophotometer (Jenway-UV-VIS spectrophotometer), based on a colorimetric oxidation/ reduction reaction, as described by (Skerget et al. 2005). The used oxidizing reagent was the Folin-Ciocalteu reagent (AOAC, 2007).

Radical scavenging activity (RSA)

The electron donation ability of the obtained extracts was measured by bleaching of the purple-coloured solution of the 2,2-diphenyl-1-picrylhydrazyl radical (DPPH-) according to (Hanato et al., 1988) and the modified method by (Gulcin et al., 2004).

\section{Rheological measurements}

The viscosity and released whey from yoghurt samples were measured according to Aryana (2003). The quantity of whey, collected from each sample in the graduated cylinder after $2 \mathrm{~h}$ of drainage at $20^{\circ} \mathrm{C}$, was used as an index of syneresis. The viscosity of yohgurt samples was determined using the Rotational Viscometer Type LabLine Model 5437. Results were expressed as CPS.

\section{Microbiological analysis}

The total bacterial count (TBC) was determined using the plate count agar method (Houghtby et al., 1992), The enumeration of $S$. thermophilus was accomplished after incubation at $37^{\circ} \mathrm{C}$ for $48 \mathrm{~h}$ under anaerobic conditions using M17agar (Oxide Ltd). L. acidophilus counts were determined using MRS-sorbitol agar (Oxide Ltd), and the plates were incubated in anaerobic conditions at $37^{\circ} \mathrm{C}$ for 72 h (Dave and Shah, 1996). B. bifidum counts were enumerated according to Dinakar and Mistry (1994) using a modified MRS agar media and the plates were incubated in anaerobic conditions at $37^{\circ} \mathrm{C}$ for $72 \mathrm{~h}$., yeasts \& moulds counts were enumerated according to Marshall (1992). All the results were recorded as a log number of colony-forming units per $\mathrm{g}(\mathrm{cfu} / \mathrm{g})$.

Sensory evaluation

The sensory properties of yoghurt samples were assessed by ten panel members of the Dairy branch, Food Science Department, Faculty of Agriculture, Zagazig University. Score points were 50 for flavour, 35 for body and texture and 15 for colour and appearance, which give a total score of 100 points (El-Shazly et al., 2008).

Statistical analysis

The obtained results were evaluated statistically using analysis of variance as reported by McClave and Benson (1991). P value of less than 0.05 was considered statistically significant. SPSS (Chicago, IL, USA) software window Version 16 was used.

\section{RESULTS AND DISCUSSION}

\section{Chemical composition and antioxidant properties of guava seeds powder (GSP)}

The macronutrient contents of GSP are given in Table 1. Moisture, protein, fat, ash and crude fiber contents of GSP were $6.20,11.20,14.10,1.30$, and $64.0 \mathrm{~g} / 100 \mathrm{~g}$, respectively. These results are in agreement with those obtained by (Uchôa-Thomaz et al., 2014). TPC of ethanolic GSP extract was 320.14 (mg gallic acid equivalent / $100 \mathrm{~g}$ dry weight), while the radical scavenging activity RSA (\%) of ethanolic GSP extract was $88.3 \%$.

Table 1. Chemical composition, Total phenols and antioxidant activity of guava seeds powder (GSP)

\begin{tabular}{lc}
\hline Component & Value \pm SD \\
\hline \multicolumn{2}{c}{ Chemical composition (g/100g) } \\
Moisture & $6.20 \pm 0.25$ \\
Total Protein & $11.2 \pm 0.4$ \\
Crude oil & $14.1 \pm 0.4$ \\
Ash & $1.30 \pm 0.1$ \\
Crude Fiber & $64.0 \pm 3$ \\
\hline \multicolumn{2}{c}{ Total phenols and antioxidant activity } \\
Total phenolic compounds (mg gallic equivalent / \\
100 g DW) \\
Radical scavenging activity (RSA, \%) \\
\hline DW:
\end{tabular}

DW: dry weight

Chemical composition of probiotic low-fat yoghurt supplemented with GSP:

Table 2 shows that yoghurt made from milk containing $3 \%$ fat $(\mathrm{C} 1)$ had the highest total solids (TS) and it was significantly $(\mathrm{p} \leq 0.05)$ different from all yoghurt treatments. While the probiotic low-fat yoghurt treatments exhibited the least TS content. This decrease in TS was due to the fat separation from milk yoghurt treatments. The TS content of probiotic low-fat yoghurt supplemented with GSP increased gradually by increasing the percentage added. The TS content of all yoghurt treatments slightly increased during the storage period. 
Table 2. Chemical analysis of probiotic low-fat yoghurt supplemented with guava seeds powder (GSP) during storage at $4^{\circ} \mathrm{C}$ for 15 days

\begin{tabular}{|c|c|c|c|c|c|}
\hline \multirow{2}{*}{$\begin{array}{l}\text { Storage } \\
\text { period (day) }\end{array}$} & \multicolumn{5}{|c|}{ Treatment } \\
\hline & C1 & $\mathrm{C2}$ & T1 & $\mathbf{T 2}$ & T3 \\
\hline \multicolumn{6}{|c|}{ Total solids (\%) } \\
\hline Fresh & $11.90^{\mathrm{a}}$ & $10.28^{\mathrm{d}}$ & $10.34^{\mathrm{cd}}$ & $10.86^{c}$ & $11.12^{\mathrm{b}}$ \\
\hline 5 & $12.06^{\mathrm{a}}$ & $10.90^{\mathrm{d}}$ & $11.12^{\text {cd }}$ & $11.42^{c}$ & $11.94^{\mathrm{b}}$ \\
\hline 10 & $12.92^{\mathrm{a}}$ & $11.26^{\mathrm{d}}$ & $11.82^{\mathrm{cd}}$ & $12.04^{\mathrm{c}}$ & $12.48^{\mathrm{b}}$ \\
\hline 15 & $13.20^{\mathrm{a}}$ & $11.88^{\mathrm{d}}$ & $12.36^{\mathrm{cd}}$ & $12.92^{\mathrm{c}}$ & $13.26^{\mathrm{b}}$ \\
\hline \multicolumn{6}{|c|}{ Fat (\%) } \\
\hline Fresh & $3.12^{\mathrm{a}}$ & $1.12^{\mathrm{b}}$ & $1.30^{\mathrm{b}}$ & $1.38^{\mathrm{b}}$ & $1.44^{\mathrm{b}}$ \\
\hline 5 & $3.26^{\mathrm{a}}$ & $1.45^{\mathrm{bc}}$ & $1.58^{\mathrm{b}}$ & $1.64^{\mathrm{b}}$ & $1.76^{\mathrm{b}}$ \\
\hline 10 & $3.48^{\mathrm{a}}$ & $1.62^{\mathrm{bc}}$ & $1.75^{\mathrm{b}}$ & $1.82^{\mathrm{b}}$ & $1.80^{\mathrm{b}}$ \\
\hline 15 & $3.80^{\mathrm{a}}$ & $1.74^{\mathrm{bc}}$ & $1.88^{\mathrm{bc}}$ & $2.00^{\mathrm{b}}$ & $2.12^{\mathrm{b}}$ \\
\hline \multicolumn{6}{|c|}{ Total protein (\%) } \\
\hline Fresh & $3.50^{c}$ & $3.74^{\mathrm{b}}$ & $4.04^{\mathrm{ab}}$ & $4.16^{\mathrm{a}}$ & $4.28^{\mathrm{a}}$ \\
\hline 5 & $3.64^{\mathrm{c}}$ & $3.95^{\mathrm{b}}$ & $4.25^{\mathrm{ab}}$ & $4.48^{\mathrm{a}}$ & 4. $62^{\mathrm{a}}$ \\
\hline 10 & $3.82^{\mathrm{c}}$ & 4. $12^{\mathrm{b}}$ & $4.54^{\mathrm{ab}}$ & $4.84^{\mathrm{a}}$ & $4.96^{\mathrm{a}}$ \\
\hline 15 & $4.10^{c}$ & $4.34^{\mathrm{b}}$ & $4.98^{\mathrm{ab}}$ & 5. $20^{\mathrm{a}}$ & $5.36^{\mathrm{a}}$ \\
\hline \multicolumn{6}{|c|}{ Fiber } \\
\hline Fresh & ND & ND & $1.18^{\mathrm{c}}$ & $1.72^{\mathrm{b}}$ & $1.94^{\mathrm{a}}$ \\
\hline 5 & ND & ND & $1.40^{\mathrm{c}}$ & $1.96^{\mathrm{b}}$ & $2.18^{\mathrm{a}}$ \\
\hline 10 & ND & ND & $1.94^{\mathrm{c}}$ & $2.20^{\mathrm{b}}$ & $2.62^{\mathrm{a}}$ \\
\hline 15 & ND & ND & $2.18^{c}$ & $2.44^{\mathrm{b}}$ & $2.84^{\mathrm{a}}$ \\
\hline \multicolumn{6}{|c|}{$\mathrm{pH}$} \\
\hline Fresh & $4.62^{\mathrm{a}}$ & $4.60^{\mathrm{a}}$ & $4.56^{\mathrm{b}}$ & $4.58^{\mathrm{ab}}$ & $4.54^{\mathrm{bc}}$ \\
\hline 5 & $4.54^{\mathrm{a}}$ & $4.40^{\mathrm{b}}$ & $4.28^{c}$ & $4.12^{\mathrm{d}}$ & $4.00^{\mathrm{e}}$ \\
\hline 10 & $4.48^{\mathrm{a}}$ & $4.22^{\mathrm{b}}$ & 4. $02^{\mathrm{c}}$ & $3.94^{\mathrm{d}}$ & $3.90^{\mathrm{e}}$ \\
\hline 15 & $4.32^{\mathrm{a}}$ & $4.05^{\mathrm{b}}$ & $3.90^{\mathrm{c}}$ & $3.82^{\mathrm{d}}$ & $3.78^{\mathrm{e}}$ \\
\hline \multicolumn{6}{|c|}{ Acidity (as lactic acid \%) } \\
\hline Fresh & $0.85^{\mathrm{a}}$ & $0.86^{\mathrm{a}}$ & $0.84^{\mathrm{a}}$ & $0.82^{\mathrm{b}}$ & $0.80^{\mathrm{b}}$ \\
\hline 5 & $0.92^{\mathrm{b}}$ & $0.98^{\mathrm{a}}$ & $0.95^{\mathrm{ab}}$ & $0.90^{\mathrm{bc}}$ & $0.86^{\mathrm{c}}$ \\
\hline 10 & $1.04^{\mathrm{ab}}$ & $1.14^{\mathrm{a}}$ & $1.08^{\mathrm{ab}}$ & $0.98^{\mathrm{b}}$ & $0.94^{\mathrm{b}}$ \\
\hline 15 & $1.16^{\mathrm{bc}}$ & $1.38^{\mathrm{a}}$ & $1.20^{\mathrm{b}}$ & $1.08^{\mathrm{c}}$ & $1.02^{\mathrm{c}}$ \\
\hline
\end{tabular}

* Values (means \pm SD) with different superscript letters are statistically significantly different $(P \leq \mathbf{0 . 0 5})$.

ND: not determined

C1: Probiotic control yoghurt (3\% fat).

C 2: Probiotic low-fat yoghurt (1\% fat).

T1: Probiotic low-fat yoghurt supplemented with 1\% GSP

T2: Probiotic low-fat yoghurt supplemented with 2\% GSP

T3: Probiotic low-fat yoghurt supplemented with 3\% GSP

Lowering fat content in the probiotic low-fat yoghurt milk slightly increased the total protein in low-fat yoghurt compared with full-fat yoghurt (C1). The total protein of low-fat yoghurt supplemented with GSP slightly increased by increasing the percentage added. The total protein of all yoghurt treatments slightly increased during the storage period. Control yoghurt (C1) contained high fat content was significantly $(\mathrm{p} \leq 0.05)$ different from other treatments .

The fat content increased gradually with the increase in the percentage of GSP. This may be due to the fact that guava seeds powder contains about $14.1 \%$ crude fat. These results agree with those reported by Maurya (2015.)

Dietary (DF) content was increased by adding guava seeds powder in the yoghurt. The DF may offer physiological effects on viscosity, solubility, oil-binding capacity, hydration property and antioxidant activity in food products. Jambi (2018) used date pits powder as a source of DF for improving the rheological properties of yoghurt. The results are in agreement with those reported by Hasani et al. (2017), who studied the effect of different amounts of barley bran on the physicochemical properties of low-fat yoghurt. Al-Hamdani et al. (2015) mentioned that supplemented yoghurt with 2 and $4 \%$ of lupine flour had the highest positive effect on physicochemical properties.

The acidity of all yoghurt treatments slightly increased during the storage period. Changes in $\mathrm{pH}$ value of yoghurt from different treatments followed almost the opposite trend to acidity. The results are in disagreement with those reported by Al-Hamdani et al. (2015) and Hasani et al. (2017) who found that supplementation of low-fat yoghurt with barley or lupine flour decreased the acidity.

TPC and RSA of probiotic yoghurt enriched with GSP

TPC and RSA of yoghurt prepared with different ratios of GSP are given in Table 3. TPC of yoghurt prepared with GSP was increased by increasing GSP \% in the yoghurt. RSA of yoghurt prepared with GSP was increased as GSP increased in the yoghurt product. The TPC and RSA of all yoghurt treatments decreased during the storage period. These results are in harmony with those reported by Jambi (2018) who found that TPC and RSA of yoghurt prepared with date pits powder were increased as date pits powder ratio increased in the yoghurt product.

Table 3. The effect of different ratio of guava seeds powder (GSP) on Total phenolic content (TPC) and Radical scavenging activity (RSA) of probiotic low fat produced yoghurt

\begin{tabular}{lccccc}
\hline $\begin{array}{l}\text { Storage } \\
\text { period }(\text { day) }\end{array}$ & C1 & C2 & T1 & T3 & T3 \\
\cline { 2 - 6 } \multicolumn{5}{c}{ Total phenolic content $(\mathrm{mg}$ gallic equivalent / 100 g DW) } \\
Fresh & $4.60^{\mathrm{e}}$ & $3.42^{\mathrm{d}}$ & $46.10^{\mathrm{c}}$ & $75.32^{\mathrm{b}}$ & $120.07^{\mathrm{a}}$ \\
5 & $3.70^{\mathrm{e}}$ & $3.58^{\mathrm{d}}$ & $42.85^{\mathrm{c}}$ & $65.41^{\mathrm{b}}$ & $107.01^{\mathrm{a}}$ \\
10 & $3.20^{\mathrm{e}}$ & $2.56^{\mathrm{d}}$ & $38.16^{\mathrm{c}}$ & $62.02^{\mathrm{b}}$ & $97.24^{\mathrm{a}}$ \\
15 & $2.70^{\mathrm{e}}$ & $2.38^{\mathrm{d}}$ & $34.43^{\mathrm{c}}$ & $55.16^{\mathrm{b}}$ & $90.28^{\mathrm{a}}$ \\
\hline \multicolumn{5}{c}{ Fresh } & Radical scavenging activity (RSA, \%) \\
5 & $20.80^{\mathrm{e}}$ & $22.36^{\mathrm{d}}$ & $50.14^{\mathrm{c}}$ & $60.20^{\mathrm{b}}$ & $75.32^{\mathrm{a}}$ \\
10 & $18.72^{\mathrm{e}}$ & $15.75^{\mathrm{d}}$ & $38.78^{\mathrm{c}}$ & $52.80^{\mathrm{b}}$ & $64.86^{\mathrm{a}}$ \\
15 & $12.78^{\mathrm{e}}$ & $9.82^{\mathrm{d}}$ & $26.85^{\mathrm{c}}$ & $44.84^{\mathrm{b}}$ & $50.90^{\mathrm{a}}$ \\
\hline
\end{tabular}

* Values (means \pm SD) with different superscript letters are statistically significantly different $(P \leq 0.05)$.

DW: dry weight

C1: Probiotic Control yoghurt (3\% fat).

C 2: Probiotic Low-fat yoghurt (1\% fat).

T1: Probiotic low-fat yoghurt supplemented with $1 \%$ GSP

T2: Probiotic low-fat yoghurt supplemented with 2\% GSP

T3: Probiotic low-fat yoghurt supplemented with 3\% GSP

Rheological properties of probiotic low-fat yoghurt supplemented with GSP

Separation of whey was increased by decreasing the fat content in yoghurt. However, supplementation of yoghurt with GSP significantly reduced whey syneresis compared with low-fat yoghurt without additives (C2). This reduction was proportional to the supplementation ratio (Table 4). The whey syneresis of yoghurt treatments increased during the storage period. It was reported that reduction of fat content in yoghurt resulted in lower gel strength and firmness than full-fat yoghurt, as a consequence of a lower number of fat globules embedded in the protein network Duboc and Mollet (2003). These results might be due to increasing the water holding capacity by GSP in the resultant curd. A similar observation was found by (Behnia et al. (2013) in fresh yoghurt containing cress seed gum.

Probiotic low-fat yoghurt (C2) was significantly less viscous than $3 \%$ fat yoghurt $(\mathrm{C} 1)$. Supplementation of 
yoghurt milk with GSP significantly increased the viscosity of the resultant yoghurt. The increase was slightly proportional to the rate of addition. This increase could be attributed to the water hydration of GSP. The viscosity of yoghurt treatments increased during the storage period. Similar results were reported by Hassan et al. (2015), who found that the addition of cress seed mucilage or guar gum to yoghurt reduced its whey syneresis and increased viscosity than control yoghurt.

Table 4. Rheological properties of low-fat yoghurt as affected by adding guava seeds powder (GSP) during storage at $4^{\circ} \mathrm{C}$ for 15 days

\begin{tabular}{lccccc}
\hline \multirow{2}{*}{$\begin{array}{l}\text { Storage } \\
\text { period (day) }\end{array}$} & C1 & C2 & T1 & T3 & T3 \\
\cline { 2 - 6 } & \multicolumn{5}{c}{ Whey syneresis $(\mathrm{ml} / 100 \mathrm{gm})$} \\
Fresh & $26.00^{\mathrm{e}}$ & $36.00^{\mathrm{a}}$ & $32.00^{\mathrm{b}}$ & $30.00^{\mathrm{c}}$ & $28.00^{\mathrm{d}}$ \\
5 & $30.00^{\mathrm{e}}$ & $39.00^{\mathrm{a}}$ & $37.00^{\mathrm{b}}$ & $33.00^{\mathrm{c}}$ & $31.00^{\mathrm{d}}$ \\
10 & $33.00^{\mathrm{e}}$ & $44.00^{\mathrm{a}}$ & $40.00^{\mathrm{b}}$ & $37.00^{\mathrm{c}}$ & $34.00^{\mathrm{d}}$ \\
15 & $36.00^{\mathrm{e}}$ & $49.00^{\mathrm{a}}$ & $45.00^{\mathrm{b}}$ & $41.00^{\mathrm{c}}$ & $38.00^{\mathrm{d}}$ \\
\hline \multicolumn{5}{c}{ Viscosity $(\mathrm{cps})^{\mathrm{y}}$} \\
Fresh & $5300^{\mathrm{a}}$ & $4100^{\mathrm{e}}$ & $4400^{\mathrm{d}}$ & $4700^{\mathrm{c}}$ & $5100^{\mathrm{b}}$ \\
5 & $5450^{\mathrm{a}}$ & $4300^{\mathrm{e}}$ & $4480^{\mathrm{d}}$ & $4770^{\mathrm{c}}$ & $5160^{\mathrm{b}}$ \\
10 & $5510^{\mathrm{a}}$ & $4420^{\mathrm{e}}$ & $4560^{\mathrm{d}}$ & $4850^{\mathrm{c}}$ & $5240^{\mathrm{b}}$ \\
15 & $5540^{\mathrm{a}}$ & $4510^{\mathrm{e}}$ & $4620^{\mathrm{d}}$ & $4920^{\mathrm{c}}$ & $5320^{\mathrm{b}}$ \\
\hline
\end{tabular}

* Values (means \pm SD) with different superscript letters are statistically significantly different $(P \leq \mathbf{0 . 0 5})$.

C1: Probiotic control yoghurt (3\% fat).

C 2: Probiotic low-fat yoghurt (1\% fat).

T1: Probiotic low-fat yoghurt supplemented with $1 \%$ GSP

T2: Probiotic low-fat yoghurt supplemented with $2 \%$ GSP

T3: Probiotic low-fat yoghurt supplemented with 3\% GSP

Microbiological evaluation of probiotic low-fat yoghurt supplemented with GSP

Table 5 shows the differences in TBC of yoghurt samples made with GSP at different concentrations. There were significant differences in viable bacterial count between control yoghurt and other yoghurt samples. The results indicated that TBC decreased gradually throughout the storage period until the end of the storage period. The obtained results also showed that low fat yoghurt samples supplemented with GSP had the highest counts of the total bacterial count.

Yeasts \& moulds counts increased gradually in all treatments up to the end of the storage period. Yoghurt treatments supplemented with GSP had the highest yeast s \& moulds counts. Streptococcus thermophilus and Lactobacillus acidophilus count decreased gradually in all treatments up to end of the storage period. Yoghurt treatments supplemented with GSP had the highest Streptococcus thermophiles, Lactobacillus acidophilus and Bifidobacterium bifidum counts.

The addition of GSP improved the viability of Streptococcus thermophilus, Lactobacillus acidophilus, and Bifidobacterium bifidum. Similar results were reported by other researchers concerning the viability and survival of $L$. acidophilus and other lactobacilli in oat mash (Akalin et al., 2012; Champagne et al., 2011).

Phuapaiboon et al. (2013), reported that the addition of pineapple to yoghurt enhanced the probiotic viability during 28 days of storage. Also, Elsanhoty and Ramadan (2018), found that supplementation of probiotic low-fat yoghurt with barley $\beta$-glucan enhanced the probiotic viability during storage. Therefore, GSP could be consider as prebiotic enhance the growth and activity of probiotic bacteria.

Table 5. Microbiological evaluation of probiotic low-fat yoghurt supplemented with guava seeds powder (GSP) during storage at $4^{\circ} \mathrm{C}$ for 15 days

\begin{tabular}{|c|c|c|c|c|c|}
\hline \multirow{2}{*}{$\begin{array}{l}\text { Storage } \\
\text { period (day) }\end{array}$} & \multicolumn{5}{|c|}{ Treatment } \\
\hline & C1 & C2 & T1 & $\mathbf{T 2}$ & T3 \\
\hline \multicolumn{6}{|c|}{ TBC $(\log$ of $\mathrm{cfu} / \mathrm{g})$} \\
\hline Fresh & 8.72 & 8.70 & 8.81 & 8.83 & 8.82 \\
\hline 5 & 8.68 & 8.75 & 8.78 & 8.80 & 8.78 \\
\hline 10 & 8.23 & 8.34 & 8.36 & 8.39 & 8.37 \\
\hline 15 & 7.60 & 7.72 & 7.74 & 7.74 & 7.77 \\
\hline \multicolumn{6}{|c|}{ Yeasts \& Moulds (log of cfu/g) } \\
\hline Fresh & ND & ND & ND & 3.11 & 3.11 \\
\hline 5 & 3.20 & 3.11 & 3.18 & 3.18 & 3.28 \\
\hline 10 & 3.30 & 3.23 & 3.26 & 3.23 & 3.32 \\
\hline 15 & 3.38 & 3.28 & 3.34 & 3.30 & 3.36 \\
\hline \multicolumn{6}{|c|}{ Lactobacillus acidophilus $(\log$ of $\mathrm{cfu} / \mathrm{g}$ ) } \\
\hline Fresh & 8.64 & 8.73 & 8.81 & 8.86 & 8.92 \\
\hline 5 & 8.60 & 8.66 & 8.76 & 8.85 & 8.91 \\
\hline 10 & 8.16 & 8.18 & 8.31 & 8.43 & 8.46 \\
\hline 15 & 7.49 & 7.53 & 7.76 & 7.99 & 8.13 \\
\hline \multicolumn{6}{|c|}{ Bifidobacterium bifidum (log of $\mathrm{cfu} / \mathrm{g}$ ) } \\
\hline Fresh & 8.60 & 8.68 & 8.78 & 8.83 & 8.87 \\
\hline 5 & 8.57 & 8.65 & 8.75 & 8.79 & 8.83 \\
\hline 10 & 8.11 & 8.16 & 8.20 & 8.32 & 8.35 \\
\hline 15 & 7.48 & 7.52 & 7.67 & 7.86 & 7.99 \\
\hline \multicolumn{6}{|c|}{ Streptococcus thermophilus (log of cfu/g) } \\
\hline Fresh & 8.70 & 8.72 & 8.77 & 8.79 & 8.76 \\
\hline 5 & 8.81 & 8.85 & 8.90 & 8.90 & 8.85 \\
\hline 10 & 8.19 & 8.38 & 8.36 & 8.41 & 8.36 \\
\hline 15 & 7.51 & 7.73 & 7.82 & 7.98 & 8.00 \\
\hline \multicolumn{6}{|c|}{$\begin{array}{l}\text { ND: not detected } \\
\text { C1: Probiotic control yoghurt (3\% fat). } \\
\text { C2: Probiotic low fat yoghurt (1\% fat). } \\
\text { T1: Probiotic low fat yoghurt supplemented with 1\% GSP } \\
\text { T2: Probiotic low fat yoghurt supplemented with 2\% GSP } \\
\text { T3: Low-fat yoghurt supplemented with 3\% GSP }\end{array}$} \\
\hline
\end{tabular}

\section{Organoleptic properties of probiotic low-fat yoghurt supplemented with GSP}

Scores of organoleptic properties flavour, body \& texture, appearance, and total scores of probiotic low-fat yoghurt without additives or with added GSP are shown in Table 6. It is evident from the results that, the reduction of milk fat in (C2) gained the lowest scores for organoleptic properties. Supplementation of low-fat milk with GSP improved the organoleptic properties of probiotic low-fat treatments and this improvement was proportional to the supplementation ratio. Probiotic low fat supplemented with $3 \%$ GSP (T3) was similar to the $3 \%$ fat yoghurt (C1). The organoleptic properties of all yoghurt treatments decreased during the storage period.

Results revealed that the GSP had a significant negative effect on colour and flavour. These results are in line with Maurya (2015) who found that GSP had a negative effect on the yoghurt in colour and appearance.

The taste followed the same trend. Slight decrease in texture and overall acceptability with no significant effect was observed. A similar observation was reported by AlHamdani et al., (2015), who found that supplementation of yoghurt with $2 \%$ and $4 \%$ of lupine flour had the highest positive effect on physicochemical and sensory scores (flavour, taste, acidity, texture and consistency, appearance, 
and total properties). To improve the textural and functional properties of low-fat yoghurt, the use of cereal fibers has been widely investigated (Hasani, 2017; Dabija et al., 2018).

Table 6. Organoleptic properties of low-fat yoghurt as affected by adding guava seeds powder( GSP) during storage at $4{ }^{\circ} \mathrm{C}$ for 15 days

\begin{tabular}{lccccc}
\hline Storage & \multicolumn{5}{c}{ Treatment } \\
\cline { 2 - 6 } period (day) & C1 & C2 & T1 & T2 & T3 \\
\hline \multicolumn{5}{c}{ Colour and appearance $(15)$} \\
Fresh & $14.00^{\mathrm{a}}$ & $12.00^{\mathrm{c}}$ & $12.50^{\mathrm{bc}}$ & $12.80^{\mathrm{bc}}$ & $13.00^{\mathrm{b}}$ \\
5 & $13.70^{\mathrm{a}}$ & $11.80^{\mathrm{c}}$ & $12.20^{\mathrm{bc}}$ & $12.50^{\mathrm{b}}$ & $12.80^{\mathrm{b}}$ \\
10 & $13.20^{\mathrm{a}}$ & $11.50^{\mathrm{bc}}$ & $12.00^{\mathrm{b}}$ & $12.30^{\mathrm{b}}$ & $12.50^{\mathrm{b}}$ \\
15 & $12.90^{\mathrm{a}}$ & $11.00^{\mathrm{c}}$ & $11.70 \mathrm{~b}^{\mathrm{c}}$ & $12.00^{\mathrm{b}}$ & $12.20^{\mathrm{b}}$ \\
\hline \multicolumn{5}{c}{ Flavour $(50)$} \\
Fresh & $48.00^{\mathrm{a}}$ & $42.00^{\mathrm{d}}$ & $46.00^{\mathrm{b}}$ & $44.00^{\mathrm{c}}$ & $44.00^{\mathrm{c}}$ \\
5 & $50.00^{\mathrm{a}}$ & $45.00^{\mathrm{bc}}$ & $49.00^{\mathrm{ab}}$ & $47.00^{\mathrm{b}}$ & $46.00^{\mathrm{b}}$ \\
10 & $45.00^{\mathrm{a}}$ & $41.00 \mathrm{~b}^{\mathrm{c}}$ & $45.00^{\mathrm{a}}$ & $42.00^{\mathrm{b}}$ & $43.00^{\mathrm{b}}$ \\
15 & $42.00^{\mathrm{a}}$ & $38.00^{\mathrm{b}}$ & $41.00^{\mathrm{a}}$ & $40.00^{\mathrm{ab}}$ & $40.00^{\mathrm{ab}}$ \\
\hline \multicolumn{5}{c}{ Body \& texture $(35)$} \\
Fresh & $34.00^{\mathrm{a}}$ & $27.00^{\mathrm{c}}$ & $30.00^{\mathrm{b}}$ & $32.00^{\mathrm{ab}}$ & $33.00^{\mathrm{a}}$ \\
5 & $34.00^{\mathrm{a}}$ & $29.00^{\mathrm{b}}$ & $30.00^{\mathrm{b}}$ & $32.00^{\mathrm{ab}}$ & $33.00^{\mathrm{a}}$ \\
10 & $31.00^{\mathrm{a}}$ & $27.00^{\mathrm{b}}$ & $27.00^{\mathrm{b}}$ & $30.00^{\mathrm{ab}}$ & $31.00^{\mathrm{a}}$ \\
15 & $30.00^{\mathrm{a}}$ & $25.00^{\mathrm{c}}$ & $27.00^{\mathrm{b}}$ & $28.00^{\mathrm{b}}$ & $30.00^{\mathrm{a}}$ \\
\hline \multicolumn{5}{c}{ Total $^{(100)}$} \\
Fresh & $96.00^{\mathrm{a}}$ & $81.00^{\mathrm{e}}$ & $88.50^{\mathrm{d}}$ & $88.80^{\mathrm{c}}$ & $90.00^{\mathrm{b}}$ \\
5 & $97.70^{\mathrm{a}}$ & $85.80^{\mathrm{e}}$ & $91.20^{\mathrm{d}}$ & $91.50^{\mathrm{c}}$ & $91.80^{\mathrm{b}}$ \\
10 & $89.20^{\mathrm{a}}$ & $79.50^{\mathrm{e}}$ & $84.00^{\mathrm{d}}$ & $84.30^{\mathrm{c}}$ & $86.50^{\mathrm{b}}$ \\
15 & $84.90^{\mathrm{a}}$ & $74.00^{\mathrm{e}}$ & $79.70^{\mathrm{d}}$ & $80.00^{\mathrm{c}}$ & $82.20^{\mathrm{b}}$ \\
\hline
\end{tabular}

* Values (means \pm SD) with different superscript letters are statistically significantly different $(P \leq \mathbf{0 . 0 5})$.

C1: Probiotic control yoghurt (3\% fat).

C2: Probiotic low-fat yoghurt (1\% fat).

T1: Probiotic low-fat yoghurt supplemented with $1 \%$ GSP.

T2: Probiotic low-fat yoghurt supplemented with 2\% GSP.

T3: Probiotic low-fat yoghurt supplemented with $3 \%$ GSP.

\section{CONCLUSION}

GSP could be used as natural additives to improve physicochemical, rheological and sensory properties of low fat yoghurt. GSP contain fiber, and thus have been suggested to fulfill the prebiotic concept, and that led to an increase in the counts of probiotic bacteria in manufactured treatments to exceed about $106 \mathrm{CFU} / \mathrm{g}$. thereby acting as prebiotics, and the produce low-fat yoghurt supplemented with GSP as symbiotic.

\section{REFERENCES}

Akalın, A., Unal, G., Dinkci, N., and Hayaloglu, A. (2012). Microstructural, textural, and sensory characteristics of probiotic yoghurt supplemented with sodium calcium caseinate or whey protein concentrate. J. Dairy Sci., 95, 3617-3628.

Al-Hamdani, M.S., Al-Anbary, E.H., and Ahmed, .M. (2015). Effect of Lupin (Lupinus albifrons) flour on microbial and sensory properties of local Yoghurt. Advances in Life Sci. and Technol., 34.1-6.

AOAC. (2007). Association of Official Analytical ChemistsOfficial Method of Analysis. (18 ${ }^{\text {th }}$ Ed.), Benjamin Franklin Station Washington, D.C., USA.

Aryana, K.J. (2003). Folic acid supplemented fat free plain set yoghurt. Int. J. Dairy Technol., 56(4): 219-222.
Behnia, A., Karazhiyan, H., Niazmand, R., and Nafchi, A.R.M., (2013). Rheological properties of low fat yoghurt containing cress seed gum. Agric. Sci. 4, 2932.

Champagne, C.P., Ross, R.P., Saarela, M., Hansen, K.F., and Charalampopoulos, D. (2011): Recommendations for the viability assessment of probiotics as concentrated cultures and in food matrices. Int. J. Food Microbiol. 149, 185-193.

Coman V., Teleky B., Mitreaa, L., Martăua, G., Szabo , K., Călinoiua, L. and Vodnar, D.(2020) Bioactive potential of fruit and vegetable wastes. Advances in Food and Nutr. Res., 91, 157-225.

Dabija, A., Codinăa, G.G., Gâtlana, A.M., and Rusu, L. (2018). Quality assessment of yogurt enriched with different types of fibers. Cyta-Journal Food. 16, 1, 859-867.

Dave, R., and Shah, N. (1996). Evaluation of media for selective enumeration of Streptococcus thermophilus, Lactobacillus delbrueckii ssp. bulgaricus, Lactobacillus acidophilus, and bifidobacteria. J. Dairy Sci., 79, 1529-1536.

Dinakar, P., and Mistry, V. (1994). Growth and viability of Bifidobacterium bifidum in Cheddar cheese. J. Dairy Sci., 77, 2854-2864.

Duboc, P., and Mollet, B. (2003). Applications of exopolysaccharides in the dairy industry. Int. Dairy. J., 11, 759-768.

Elsanhoty, R.M., and Ramadan, M.F. (2018). Changes in the physicochemical and microbiological properties of probiotic-fermented low-fat yoghurt enriched with barley $\beta$-glucan during cold storage. Mljekarstvo, 68 (4), 295-309.

El-Shazly, A.A., E., M.A. Ammar, Ismail, M.M., and Eid, M.Z. (2008). Effect of cold storage and mixing various lactations of buffaloe's and cow's milk on some properties of yoghurt. J. Agric., Sci., Mansoura Univ., 33 (7):5141-5151.

Folkenberg, D.M., and Martens, M. (2003). Sensory properties of low fat yoghurt . Part A: Effect of fat content, fermentation culture and addition of non-fat dry milk on the sensory properties of plain yoghurt. Milchwissenschaft, 58, 48-51.

Ganguly, S., Sabikhi, L., and Singh, A. K. (2019). Effect of whey-pearl millet-barley based probiotic beverage on Shigella-induced pathogenicity in murine model. J. Functional Foods, 54, 498-505.

Gulcin, I., Kufrevioglu, O.I., Oktay, M., and Buyukokuroglu, M.E. (2004). Antioxidant, antimicrobial, antiulcer and analgesic activities of nettle (Urticadioica L.). J. Ethnopharmacol. 90: 205-215.

Ganguly, S., Sabikhi, L., and Singh, A. K. (2019). Effect of whey-pearl millet-barley based probiotic beverage on Shigella-induced pathogenicity in murine model. J. Functional Foods, 54, 498-505.

Hanato, T., Kagawa, H., Yasuhara, T., and Okuda, T. (1988). Two new flavonoids and other constituents in licorice root: their relative astringency and radical scavenging effects. Chem. Pharm. Bull., 36: 2090-2097. 
Hasani, S., Sari, A.A., Heshmati, A., and Karami, M. (2017). Physico-chemical and sensory attributes assessment of functional low-fat yoghurt produced by incorporation of barley bran and Lactobacillus acidophilus. Food Sci. Nutr., 5:875-88

Hassan, L. K.; Haggag, H., El-Kalyoubi, M., Abd EL-Aziz, M., El-Sayed, M., and Sayed, A. (2015). Physicochemical properties of yoghurt containing cress seed mucilage or guar gum. Annals of Agricultural Sci., 60, (1); 21-28.

Houghtby, G., Maturin, L., and Koenig, E. (1992). Microbiological Count Methods. Standard Methods for the Examination of Dairy Products, 16, 213-246.

Hill, C., Guarner, F., Reid, G., Gibson, G. R., Merenstein, D. J., Pot, B., (2014). The International Scientific Association for Probiotics and Prebiotics consensus statement on the scope and appropriate use of the term probiotic. Nature Reviews Gastroenterology \& Hepatology, 11(8), 506-514.

Jambi, H.A. (2018). Evaluation of Physio-Chemical and Sensory Properties of Yoghurt Prepared with Date Pits Powder. Current Science International,7 (1) :1-9.

Maqsood, S., Adiamo, O., Ahmad, M., and Mudgil, P., (2019) Bioactive compounds from date fruit and seed as potential nutraceutical and functional food ingredients. Food Chemistry, 308:125522.

Marshall, R. T. (1992). Standard methods for the examination of dairy products. (16 ${ }^{\text {th }}$ ed.). Washington, USA: APHA.

Maurya, A. K., (2015). Development of crude fiber rich yoghurt and biscuits using guava seeds powder. Ph.D. Thesis. Institute of Agricultural Sciences, Banaras Hindu University, Varanasi, India.

McClave, J.T., and Benson, P. G.(1991). Statistical for business and economics. Maxwell Macmillan International editions. Dellen Publishing Co. The USA. 1991:272-295.
Phuapaiboon, P., Leenanon, B., and Levin, R.E. (2013): Effect of Lactococcus lactis immobilized within pineapple and yam bean segments, and Jerusalem Artichoke powder on its viability and quality of Yoghurt. Food and Bioprocess Technol. 6, 27512762.

Sandoval-Castilla, O., Lobato-Calleros, C., AguirreMandujano, E., and Vernon-Carter. R.J.(2004). Microstructure and texture of yoghurt as influence by fat replacers. Int. Dairy J, 14, 51-159.

Skerget, M., Kotnik, P., Hadolin, M., Rižner-Hraš, A., Simonič, M., and Knez, Z. (2005). Phenols, proanthocyanidins, flavones, and flavonols in some plant materials and their antioxidant activities. Food Chem., 89: 191-198.

Tamime, A.Y. (2006) Fermented Milks. Oxford: Blackwell. Uchôa-Thomaz, A.M.A., Sousa, E. C., Carioca, J.O.B., Morais, S. M., Alexandrino, C. G., Ferreir, P. A.T., Rodrigues, S.P., Thomaz, J.C. A., Silva, J.N. and Rodrigues, L.L.(2014). Chemical composition, fatty acid profile and bioactive compounds of guava seeds (Psidium guajava L.). Food Sci. and Technol. 34(3), 485-492.

Usman, M., Samad, W. A., Fatima, B., and Shah, M. H. (2013). Pollen Parent Enhances Fruit Size and Quality in Intervarietal Crosses in Guava (Psidium guajava). Int. J. Agric. \& Biol., 15(1), 125-129.

Wang, X., Kristo, E., and LaPointe, G. (2019). Adding apple pomace as a functional ingredient in stirred-type yoghurt and yoghurt drinks, Food Hydrocolloids, DOI: $\quad$ https:// doi.org/10.1016/j.food hyd.2019.105453.

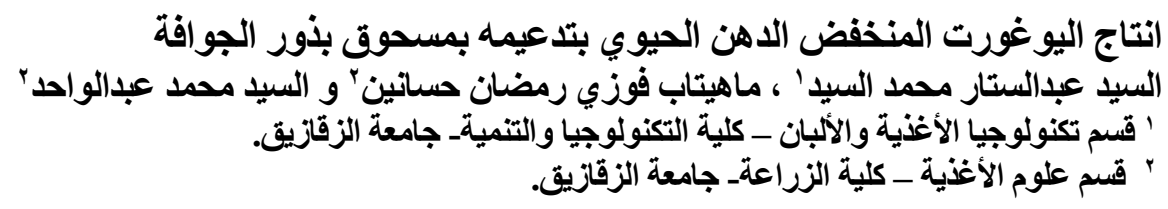

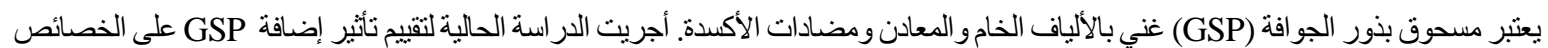

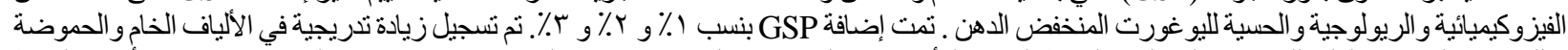

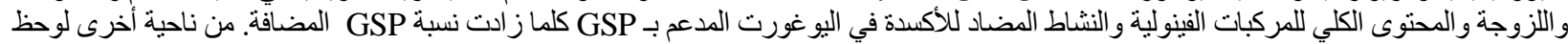

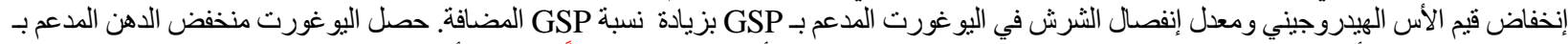

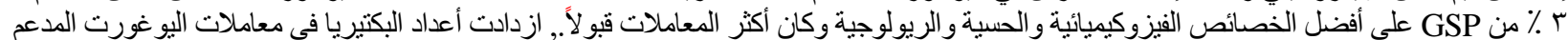

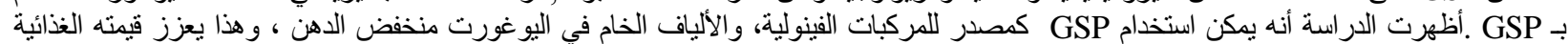

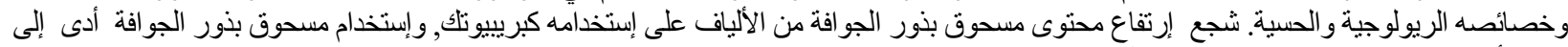

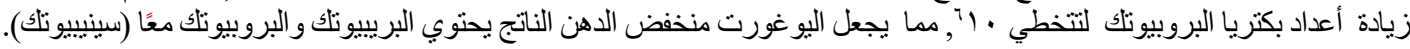

